\title{
PATTERNS OF ENDEMISM ALONG AN ELEVATION GRADIENT IN SIERRA NEVADA (SPAIN) AND LEFKA ORI (CRETE, GREECE)
}

\section{Modelos de endemicidad a lo largo de un gradiente altitudinal en Sierra Nevada (España) y Lefka Ori (Creta, Grecia)}

\author{
R. FERnÁNDEZ-CALZADO ${ }^{*}$, D. GHOSN², M. GOTTFRIED ${ }^{3}$, G. KAZAKIS ${ }^{2}$,
} J. Molero Mesa ${ }^{1}$, H. Pauli ${ }^{4} \&$ A. Merzouki ${ }^{1,5}$

1 Department of Botany, Faculty of Pharmacy, University of Granada, Campus de Cartuja, 18071, Granada, Spain

2 Mediterranean Agronomic Institute of Chania, Alsyllio Agrokepiou, 85 Chania 73100, Crete, Greece 3 Department of Conservation Biology, Vegetation and Landscape Ecology, University of Vienna, Renneweg 14, A-1030, Vienna, Austria

4 Institute of Mountain Research, Austrian Academy of Sciences, c/o Faculty Centre of Biodiversity, University of Vienna, Rennweg 14, A-1030, Vienna, Austria

5 Laboratoire d'Ethnobotanique, Dpt. de Biologie, Fac. des Sciences, Univ. Abdelmalek Essaâdi. 2121 Tétouan Maroc

* Author for correspondence. Department of Botany, Faculty of Pharmacy, University of Granada, Campus de Cartuja, 18071, Granada, Spain. E-mail: rosafc@ugr.es

ABSTRACT.- Aim: High mountains in the Mediterranean region of Europe are particularly rich in endemic vascular plants. We aimed to compare the altitudinal patterns of vascular plant species richness and the proportion of endemic species in two Mediterranean region: Lefka Ori on the island of Crete (Greece) and Sierra Nevada on the Iberian peninsula.

Location: Sierra Nevada, Granada (Spain); Lefka Ori, Crete (Greece).

Methods: Data from standardised permanent plots settings on summit sites (comprising eight plot sectors, covering the upeermost 10 altitudinal metres) of different elevations were used (GLORIA Multi-Summit approach; www.gloria.ac.at). Species numbers, rates of endemic species, and soils temperature were compared by means of ANCOVA and linear regression.

Results: The two regions, though climatically similar, showed strikingly different patterns: In Sierra Nevada, the proportion of endemic vascular plants (species restricted to Sierra Nevada) showed a stepwise increase from the lowest to 
R. FERNÁNDEZ, D. GHOSN, M. GOTTFRIED, G. KAZAKIS, J. MOLERO, H. PAULI \& A. MERZOUKI

the highest summit. In contrast, the proportion of endemic species restricted to Crete was not significantly different between the four summits in Lefka Ori. In both regions the observed trends were largely consistent with the altitudinal distribution of the endemic species obtained from standard floras.

Main conclusions: The geographic positions of the two regions, i.e. island versus mainland and the higher elevation of Sierra Nevada are suggested to be the primary causes of the observed differences.

The high degree of endemism in the cold environments of Mediterranean mountains' upper bioclimatic zones indicates a pronounced vulnerability to the impacts of climate change. A continued and intensified species monitoring in the mountains around the Mediterranean basin, therefore, should be considered as a priority research task.

Keywords: Endemism, Vascular plant species richness, Mediterranean mountains, Islands, GLORIA program, Climate warming.

RESUMEN.- Objetivo: Las zonas de alta montaña en la región mediterránea europea son particularmente ricas en plantas vasculares endémicas. Nuestro objetivo es comparar los modelos altitudinales para la riqueza de plantas vasculares y la proporción de endemismos en dos regiones mediterráneas: Lefka Ori en la isla de Creta (Grecia) y Sierra Nevada en la Península Ibérica.

Localización: Sierra Nevada, Granada (España); Lefka Ori, Creta (Grecia).

Método: Los datos proceden de un muestreo estandarizado en varias cimas situadas a diferentes altitudes (GLORIA Multi-Summit approach; www.gloria.ac.at). El número de especies, tasas de endemicidad, y temperatura del suelo se compararon por medio de ANCOVA y regresión lineal.

Resultados: Las dos regiones objeto de análisis, aunque similares climáticamente, muestran patrones llamativamente diferentes: en Sierra Nevada, la proporción de plantas vasculares endémicas (especies restringidas a Sierra Nevada) muestra un incremento gradual desde la cima más baja a la más alta. En contraste, la proporción de endemismos restringidos a Creta no fue significativamente diferente entre las cuatro cimas de Lefka Ori. Las tendencias observadas en ambas regiones fueron en gran parte consistentes con la distribución de las especies endémicas obtenida de las floras para cada región.

Conclusiones principales: La posición geográfica de ambas regiones, por ejemplo. isla frente a continente, y la mayor elevación de Sierra Nevada se sugieren como las principales causas de las diferencias observadas.

El alto grado de endemicidad en los ambientes fríos de las zonas bioclimáticas superiores de las montañas mediterráneas evidencia una marcada vulnerabilidad a los impactos del cambio climático. Por lo tanto, el seguimiento continuado e intensivo de las especies de montaña alrededor de la cuenca mediterránea, debería considerarse como una tarea investigadora prioritaria.

Palabras clave: Endemicidad, Riqueza de plantas vasculares, montañas mediterráneas, islas, proyecto GLORIA, calentamiento climático. 
PATTERNS OF ENDEMISM ALONG AN ELEVATION GRADIENT IN SIERRA NEVADA (SPAIN)...

\section{Introduction}

The degree of endemism of a region's flora is considered as a measure of the uniqueness of the flora which attracts and inspires botanists and amateurs (Van Der Werff and Consiglio, 2004). Mountain areas are often hot spots of plant diversity (Barthlott et al., 1996; Myers et al., 2000) and can host a large number of endemic species. Even though vascular plant species richness generally decreases with altitude, Europe's alpine life zone, covering around 3\% of Europe, show a disproportionately high number of species making up approximately $20 \%$ of the continents native flora (Väre et al., 2003). This high plant diversity can be attributed to a compression of thermal zones, to high habitat diversity related to rugged topography above the forest line, and to dispersal barriers between mountain ranges supporting divergent speciation. Europe shows a general south-north gradient of mountain endemism, decreasing from the Mediterranean to the temperate and further to the boreal mountains (Favarger, 1972). Mountains of the Mediterranean region remained more isolated and were only partly glaciated during the Pleistocene, (compare Blanca et al., 1998; Pauli et al., 2003; Hughes \& Woodward 2008), whereas mountains further north were more extensively or almost fully ice-covered and their margins were more connected to surrounding areas and offered migration pathways. The importance of endemic plants for the mountain vegetation in southern Europe is well documented, e.g. for Crete (Strid, 1993; Dafis et al., 1996; Phitos et al., 1996; Médail and Quézel, 1999; Bergmeier, 2002) or for the Sierra Nevada in southern Spain (Quézel, 1953; Rivas Goday and Mayor López, 1966; Molero Mesa et al,. 1996; Médail and Quézel, 1999; Mota et al., 2002).

In the present study we focus on altitudinal gradients of vascular plant species richness and the degree of endemism in two Mediterranean mountain ranges with a different geographic situation: Lefka Ori on the island of Crete and Sierra Nevada on the Iberian Peninsula. By using data from standardized permanent plot settings established on summit sites of different elevations (GLORIA Multi Summit approach; Pauli et al., 2004), we question if the two climatically similar mountain areas show similar patterns of altitudinal species distribution with respect to the proportion of endemic species.

\section{Methods}

\subsection{Study area}

The two selected Mediterranean mountain regions (Fig. 1) are part of an international network of permanent plots in alpine ecosystems (GLORIA - 


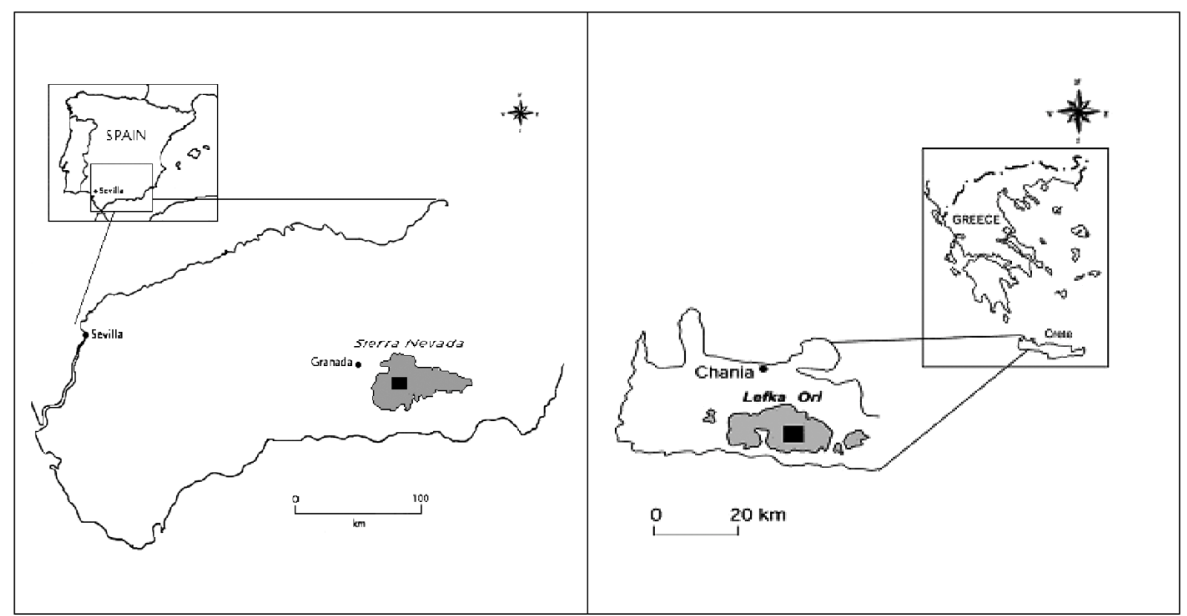

Figure 1. The study areas Sierra Nevada, Spain (left) and the Lefka Ori, Crete (right), rectangles show the position of study summits. Summit sites in Sierra Nevada: Pulpitito (2778 m), Cúpula (2968 m), Pico del Tosal Cartujo (3150 m), Cerro de los Machos (3327 m); in the Lefka Ori: Lowest summit (1964 m); Chorafas (1965 m); South-East Kakovoli (2160 m); Sternes (2339 m).

Figura 1. Las áreas de estudio: Sierra Nevada, España (izquierda) y Lefka Ori, Creta (derecha); los rectángulos muestran la posición de las cimas de estudio. Cimas en Sierra Nevada: Pulpitito (2778 m), Cúpula (2968 m), Pico del Tosal Cartujo (3150 m), Cerro de los Machos (3327 m); en Lefka Ori: Lowest summit (1964 m); Chorafas (1965 m); South-East Kakovoli (2160 m); Sternes (2339 m).

Global Observation Research Initiative in Alpine Environments; www.gloria.ac.at). Plots were setup to assess the impacts of climate change on plant species composition along a gradient from the potential climatic treeline to the uppermost bioclimatic zone of each region. The two regions were selected for this study because of (1) their exceptionally high number of endemic vascular plant species, and (2) for their similar Mediterranean-type climate with predominant winter rainfall and a pronounced dry season in summer.

The Sierra Nevada of southern Spain extends over about $80 \mathrm{~km}$ in an E-W direction and reaches its highest point at $3481 \mathrm{~m}$ a.s.l. At altitudes above 2500 $\mathrm{m}$ mean annual precipitation amounts to around $800 \mathrm{~mm}$ (Delgado et al., 2001) and falls almost exclusively as snow (Molero Mesa et al., 1996). The four studied summits were in the western, higher part of the range on siliceous bedrock. The summits ranged from $2778 \mathrm{~m}$ in the upper oro-Mediterranean zone to $3327 \mathrm{~m}$ in the upper cryoro-Mediterranean zone; for a definition of zones compare Molero Mesa and Pérez-Raya (1987). 


\section{PATTERNS OF ENDEMISM ALONG AN ELEVATION GRADIENT IN SIERRA NEVADA (SPAIN)...}
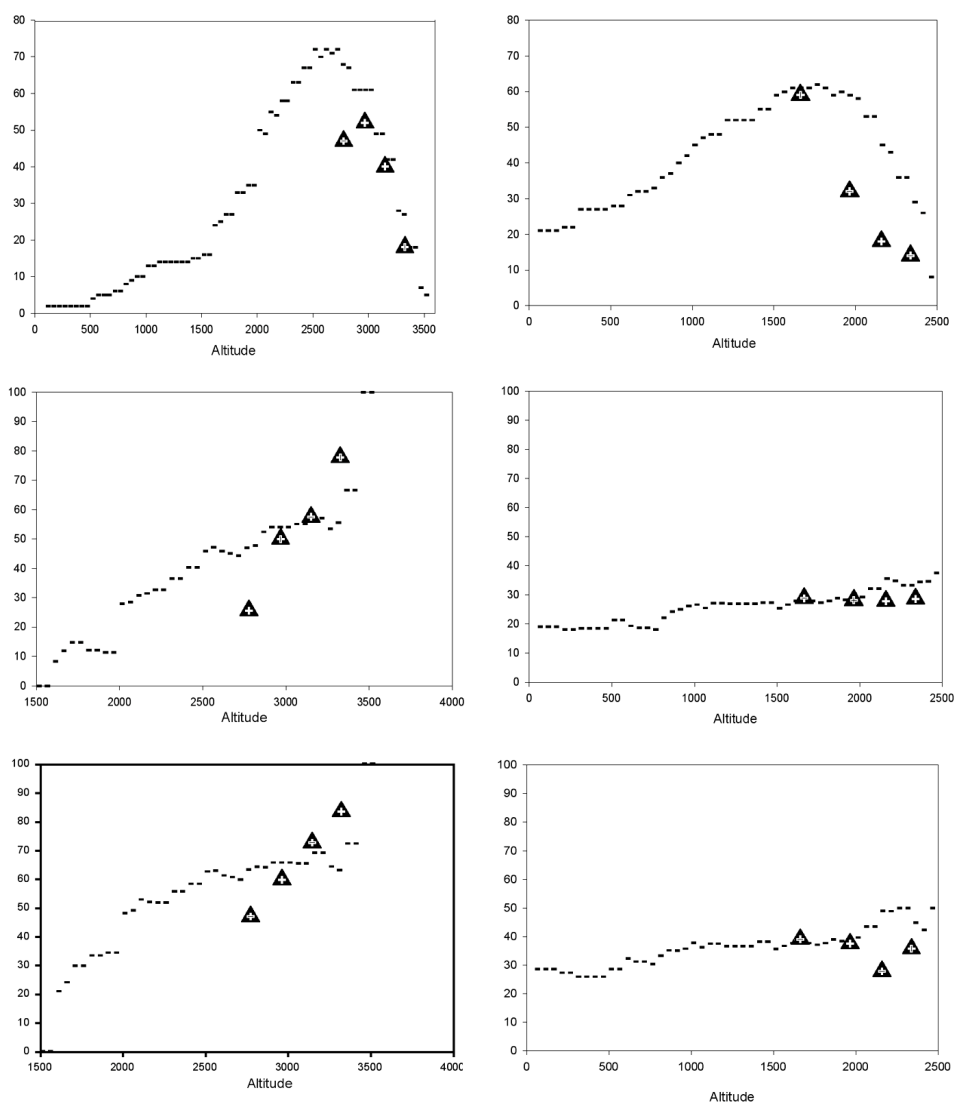

Figure 2. Altitudinal distribution of vascular plant species numbers found in the summit areas of the two study regions; left, Sierra Nevada (Spain); right, Lefka Ori (Crete). a, b, triangles: the number of species found on each summits; horizontal bars: the number out of all species found on the four summits that occur in each 50-m altitudinal band from sea level to the highest peaks (from literature data of vertical species ranges). d,c, triangles: the proportion (percentage) of local endemic species on the four summits; horizontal bars: the percentage share of locally endemic species of all summits species in the $50-\mathrm{m}$ altitudinal bands (from literature data of vertical species ranges); $\mathrm{e}, \mathrm{f}$, as before, but for regional endemic species.

Figura 2. Distribución altitudinal del número de especies de plantas vasculares en las áreas cimeras de las dos regiones de estudio; izquierda, Sierra Nevada (España); derecha, Lefka Ori (Creta). a, b, triángulos: número de especies encontradas en cada cima; barras horizontales: número de entre todas las especies encontradas en las cuatro cimas que se da en cada banda altitudinal de 50-m desde el nivel del mar hasta las cimas más altas (procedente de datos bibliográficos sobre los rangos verticales de las especies). $c, d$, triángulos: proporción (porcentaje) de especies endémicas locales en las cuatro cimas; barras horizontales: porcentaje de especies endémicas locales de todas las cimas en cada banda altitudinal de 50-m (procedente de datos bibliográficos sobre los rangos verticales de las especies); $e, f$, como la anterior pero para las especies endémicas regionales. 
The Lefka Ori region is located in the western part of Crete covering 385 $\mathrm{km}^{2}$ above $1000 \mathrm{~m}$ and reaching $2453 \mathrm{~m}$ at Pachnes summit. The massif is the wettest place on the island with 1900-2000 mm mean annual precipitation (Rackham and Moody, 1996). The summits were in the eastern part on carbonatic bedrock (marble and dolomite) and ranged from $1664 \mathrm{~m}$ in the oro-Mediterranean zone to $2339 \mathrm{~m}$ in the alti-Mediterranean zones.

\subsection{Data recording}

The sampling design used on the selected summit sites followed the GLORIA Field Manual (http:/ / www.gloria.ac.at; Pauli et al. 2004). On each summit, the area from its highest point to the 10-m contour line below the summit was surveyed. This area was subdivided into eight summit area sections (SASs). Four upper SASs extended downward to the 5-m contour line and the four lower SASs from the 5-m to the 10-m contour line. The SASs were orientated towards the cardinal geographical directions, with their boundaries set at NE, SE, SW, and NW. Within each SAS, all vascular plant species were recorded. A miniature temperature data logger (StowAway Tidbit; Onset Corporation, Bourne, Massachusetts) was buried at $10 \mathrm{~cm}$ below the soil surface in each upper SAS, approximately $4.5 \mathrm{~m}$ below the highest summit point. The temperature series measured at an interval of 1 hour between 2001 and 2002 were used in this study.

\subsection{Data analysis}

Vascular plants species numbers for each summit were derived from merging the eight SASs, and for each cardinal direction from merging the upper and the lower SASs of each aspect. Species numbers per summit were visually compared with the overall altitudinal distribution (obtained from standard floras) of the species found on the summits (Fig. 3). The relationship of percentage local endemics (le) and regional endemics (lese) on summits of different altitude was analysed by Analysis of Covariance (ANCOVA), using data of the four aspects on each summit (Fig.4 a,b,c,d). Linear regression was used to analyse the relation between yearly mean temperature and percentage of local and regional endemics (Fig.5 a,b,c,d).

A species was considered here as locally endemic when its overall distribution was restricted to Sierra Nevada or to the Island of Crete respectively; and regionally endemic when its overall distribution was restricted to the Baetic range of southern Spain or to the Aegean region, respectively (Annexe 1). 

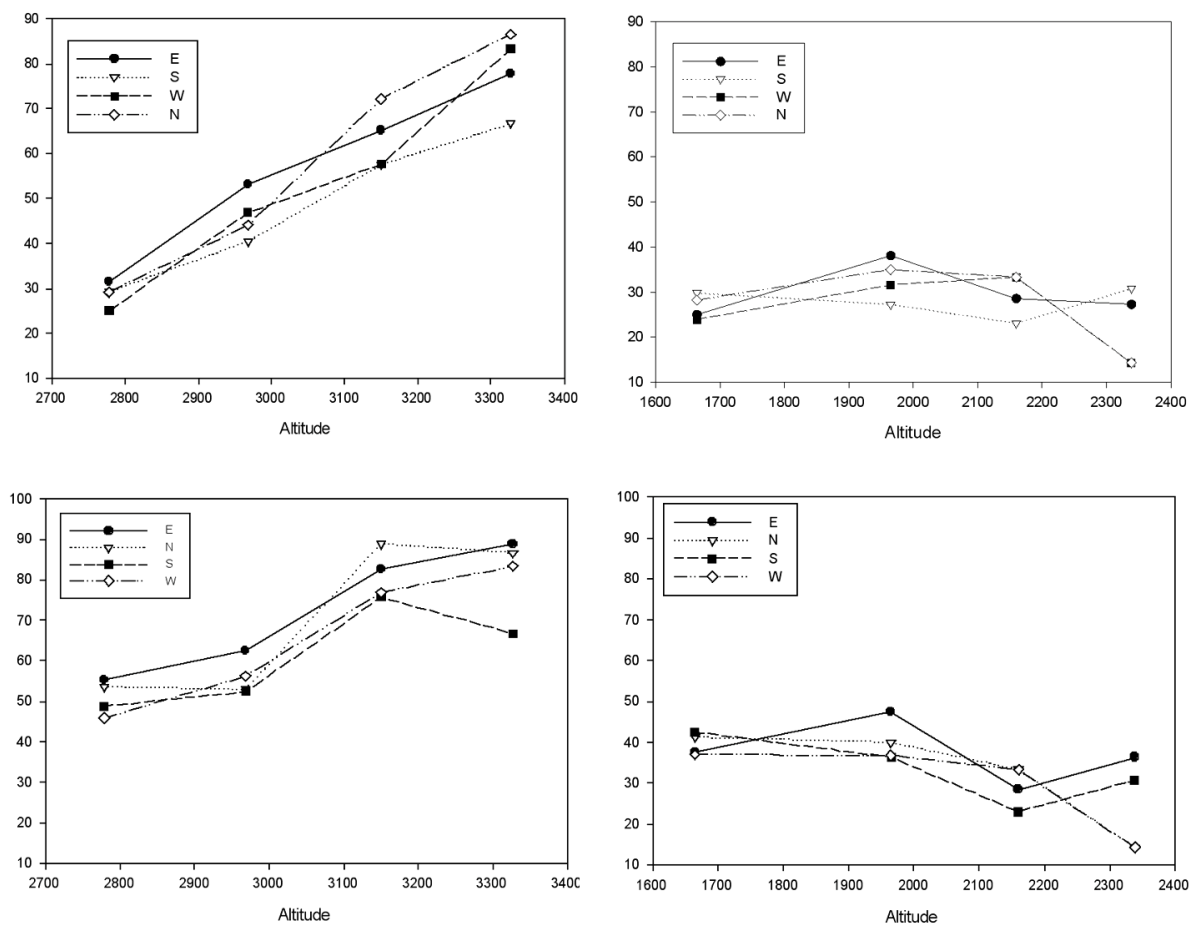

Figure 3. Proportion (percentage) of local and regional endemic vascular plants in the four cardinal directions on the study summits; (a, c) Sierra Nevada, (b, d) Lefka Ori.

Figura 3. Espectro taxonómico de las familias más relevantes en los cuadrados de muestreo.

Figura 3. Proporción (porcentaje) de plantas vasculares endémicas locales y regionales en las cuatro orientaciones de las cimas de estudio; $(a, c)$ Sierra Nevada, $(b, d)$ Lefka Ori.

The information about the distribution and altitudinal ranges of the species were extracted from several bibliographic references. In the case of Sierra Nevada, the literature sources were Flora Iberica (Castroviejo et al., 1986-1997) and Molero Mesa and Pérez-Raya (1987) in cases not yet treated in Flora Iberica. For Lefka Ori, sources were Jahn and Schönfelder (1995) and Strid and Tan (1991). Altitudinal species ranges in metres above sea level, indicated in the above standard floras and check lists, were used. The nomenclature of taxon names followed Flora Europaea (Tutin et al., 1964 - 1980). 

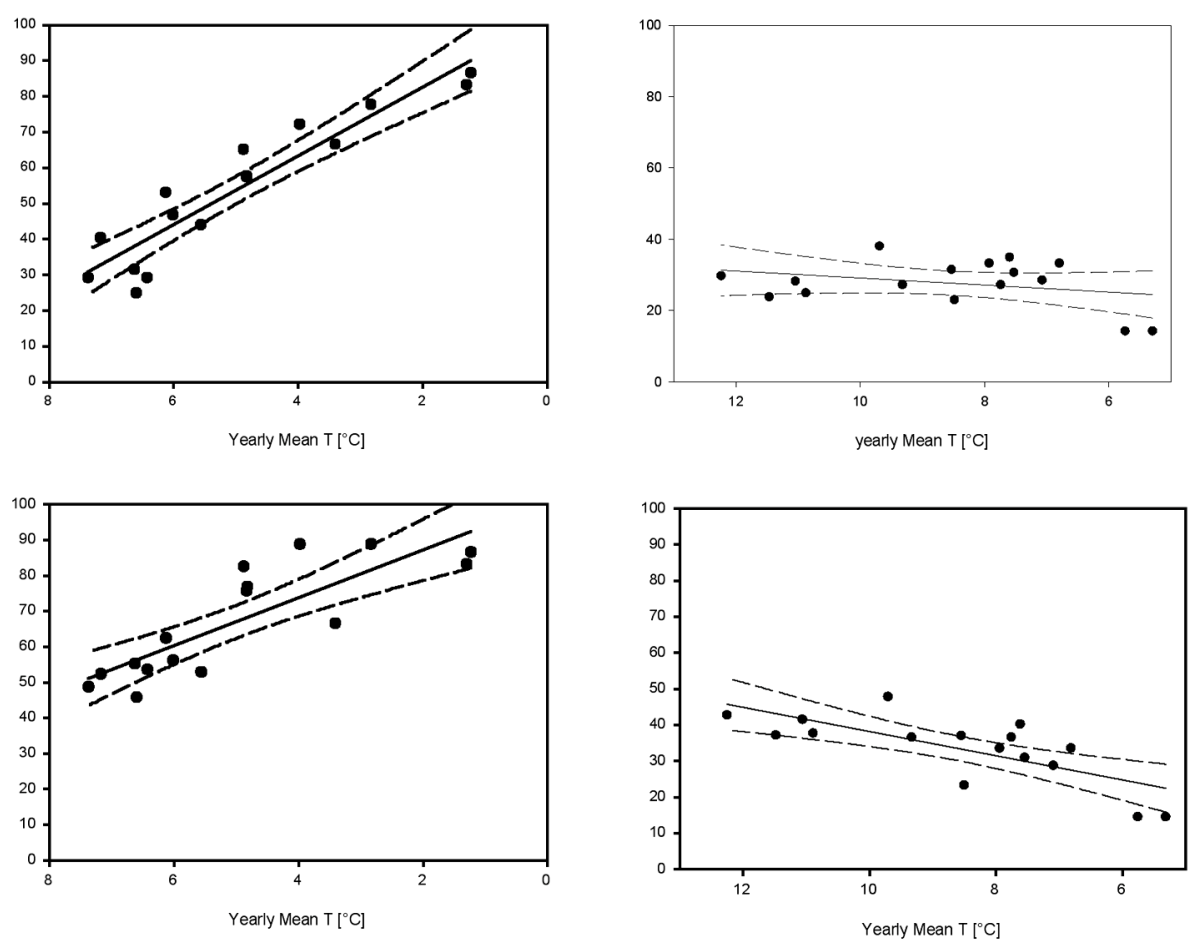

Figure 4. Percentage of local and regional endemics against yearly mean soil temperature. a, c Sierra Nevada, b, d Lefka Ori. Broken lines indicate the 95\% confidence intervals.

Figura 4. Porcentaje de endemismos locales y regionales frente a temperatura media anual del suelo. $a, c$ Sierra Nevada, b, d Lefka Ori. Las líneas discontinuas indican los intervalos del 95\% de confianza.

\section{Results}

Total vascular plant species richness on the study summits was decreasing with increasing elevation in both regions, but with the exception of the second-lowest peak in Sierra Nevada, showing slightly higher species numbers than the lowest one. The altitudinal distribution (obtained from literature sources) of the species found on the summits in Sierra Nevada ranged from almost sea level to the maximum altitude for around $3500 \mathrm{~m}$ a.s.l., but shows a pronounced peak between 2500 and $3000 \mathrm{~m}$ a.s.l. (Fig. 2a). A similar pattern, however, with a less pronounced peak between 1500 and $2000 \mathrm{~m}$ a.s.l. resulted from the Lefka Ori data (Fig. 2b). 
The proportion of locally endemic species along the full altitudinal gradient (vertical ranges obtained from literature sources) shows a distinct increase with elevation in Sierra Nevada from no endemic species at $1500 \mathrm{~m}$ to $100 \%$ endemics at $3500 \mathrm{~m}$ (Fig. 2c), whereas only a weak altitudinal trend was found for Lefka Ori, ranging from $20 \%$ endemics between 0 and $500 \mathrm{~m}$ to and $35-40 \%$ endemics above around $2200 \mathrm{~m}$ (Fig. 2d). The patterns for regional endemics were similar to the local endemics, apart from the second highest peak in Lefka Ori (Fig. 2e, f).

The proportion of local endemic as well as of regional endemic vascular plant species in Sierra Nevada showed a significant increase from the lowest to the highest site (Fig. 3a, c; Table 1, p <0.001). This was not the case in Lefka

Table 1. Summary of the results from ANCOVA and linear regression. TRC: target region. LEO: Lefka Ori. SNE: Sierra Nevada. Le: local endemics. Lese: regional endemics (these generally include also the local endemics). Perc_le: percentage of local endemics. Perc_lese: percentage of regional endemics (these generally include also the local endemics). Sualt: altitude of summit. yM: yearly mean soil temperature.

Tabla 1. Resumen de los resultados de ANCOVA y regresión lineal. TRC: target region. LEO: Lefka Ori. SNE: Sierra Nevada. Le: endemismos locales. Lese: endemismos regionales (éstos, por lo general, también incluyen a los endemismos locales). Perc_le: porcentaje de endemismos locales. Perc_lese: porcentaje de endemismos regionales (éstos, por lo general, también incluyen a los endemismos locales). Sualt: altitud de la cima. Y M: temperatura media anual del suelo.

\begin{tabular}{|c|c|c|c|c|c|c|c|c|c|c|}
\hline $\operatorname{TR}$ & Endemica & Model design & Anabris & Source & if & 55 & w & $\mathbf{F}$ & $\mathbf{P}$ & Rzz adiusted \\
\hline \multirow[t]{6}{*}{ SNE } & Is & perc_le=|rntersept+SUALT+Aspest+Aspect×SUALT & ANCOVA & Corrected Model & 3 & 5929074 & 847.911 & 53.210 & 0.000 & 0.967 \\
\hline & & & & Intercept & 1 & $35 \% 2.557$ & 3582.557 & 267.357 & 0.000 & \\
\hline & & & & SUALT & 1 & 5549.154 & 5549.154 & 414.120 & 0.000 & \\
\hline & & & & Aspect & 3 & 139.969 & 46.656 & 3.482 & 0.070 & \\
\hline & & & & Aspect" SUALLT & 3 & 156452 & 52.151 & 3.892 & 0.055 & \\
\hline & & & & & 8 & 107.199 & 13.400 & & & \\
\hline \multirow[t]{6}{*}{ SNE } & lese & 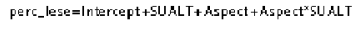 & ANCOUA & Corrected Model & $?$ & 3146.978 & 449.568 & 6.852 & $0.00 ?$ & 0.782 \\
\hline & & & & Intercept & 1 & 1159.644 & 1159.644 & 17.676 & 0.003 & \\
\hline & & & & SUALT & 1 & 2720.221 & 2720.221 & 41.452 & 0.000 & \\
\hline & & & & Aispect & 3 & 91.255 & 30.418 & 0.454 & 0.716 & \\
\hline & & & & Aspect* SUALLT & 3 & 100.412 & 36.137 & 0.551 & 0.662 & \\
\hline & & & & Error & 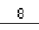 & 524.958 & 65.607 & & & \\
\hline \multirow[t]{6}{*}{ EO } & le & 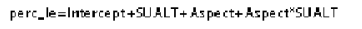 & ANCOV Vh & Corrected Model & 3 & 119.532 & 17.076 & 0.254 & 0.956 & 0.182 iurad jus ste do \\
\hline & & & & Intercept & 1 & 399036 & 399.036 & 5.929 & 0.041 & \\
\hline & & & & SUALT & 1 & 41738 & 41.738 & 0.620 & 0.454 & \\
\hline & & & & Aspect & 3 & 41321 & 13.774 & 0.205 & 0.890 & \\
\hline & & & & Aspe tT" SUALLT & 3 & 46.473 & 15.491 & 0.230 & 0.873 & \\
\hline & & & & Error & 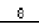 & 530.414 & 67.902 & & & \\
\hline \multirow[t]{6}{*}{ EOO } & lese & 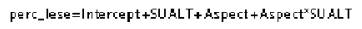 & ANCOUA & Corrected Model & $?$ & 817.979 & 116.854 & 1.868 & 0.200 & 0.288 \\
\hline & & & & Inter $\operatorname{cept}$ & 1 & 1647.755 & 1647.755 & 26.347 & 0.001 & \\
\hline & & & & SUALT & 1 & 599,396 & 599.396 & 9.584 & 0.015 & \\
\hline & & & & Aspect & 3 & 85.265 & 28.422 & 0.454 & 0.721 & \\
\hline & & & & Aspect ${ }^{\times}$SUALLT & 3 & 108.250 & 36.083 & $0.57 ?$ & 0.646 & \\
\hline & & & & Errsor & $\theta$ & 500.221 & 52.540 & & & \\
\hline \multirow[t]{2}{*}{ SNE } & 1\% & 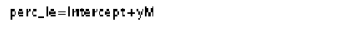 & 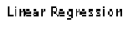 & 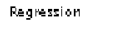 & 1 & 5254,412 & 5254.412 & 94.095 & 0.000 & 0.661 \\
\hline & & & & Residual & 14 & 701.062 & 55.047 & & & \\
\hline \multirow[t]{2}{*}{ SNE } & lese & $p=r c_{-}$lese $=$Intercept $+y \mathrm{M}$ & Lirear Regression & Regression & 1 & 2559.121 & 2553.121 & 31.951 & 0.000 & 0.674 \\
\hline & & & & Residual & 14 & 1119.710 & 79.900 & & & \\
\hline \multirow[t]{2}{*}{ EO } & log & 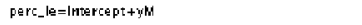 & Linear Fagression & Fegrassion & 1 & 58.533 & $58.5 \% 3$ & 1.367 & 0.252 & 0.024 \\
\hline & & & & Residual & 14 & 599.414 & 42.915 & & & \\
\hline \multirow[t]{2}{*}{ LFO } & lese & perc_lese = Intercept +yM & Lirear Fegres sion & Regress ion & 1 & 705.234 & 705.234 & 16.105 & 0.001 & 0.535 \\
\hline & & & & Residual & 14 & E180EE & 43.790 & & & \\
\hline
\end{tabular}


Ori. Here the percentage of local endemics did not significantly change from the lowest to the highest site (Fig. 3b; Table $1, p=0.45$ ), and slightly decrease with elevation in the case of regional endemics (Fig. 3d; Table $1, p=0.015$ ). No significant differences in the percentage of local and regional endemics in relation to slope exposures were found (Fig. 3; Table 1).

In Sierra Nevada, the percentage of both local and regional endemic species was related to yearly mean soil temperature, showing an increase of the proportion of endemics with decreasing temperature (Fig. 4a, c; Table 1, $p<0.001)$. In Lefka Ori , local endemics did not show this relation, and the proportion of regional endemics was negatively related to soil temperature, corresponding to their proportional decreases with altitude (Fig. 4b, d; Table 1).

\section{Discussion}

Although both Sierra Nevada and Lefka Ori are located in the southern European Mediterranean zone, we observed distinct differences regarding the altitudinal patterns of endemic vascular plant species: the proportion of endemic species (local and regional) was increasing with elevation in Sierra Nevada, whereas it remained rather constant along the altitudinal gradient in Lefka Ori.

The difference in the geographic position, island versus mainland, and the high elevation of Sierra Nevada are suggested to be the primary reasons for the strikingly different patterns. In Sierra Nevada, being by far the highest mountain range in the southern Iberian peninsula, historic (Pleistocene) as well as present orographic isolation appear to have supported endemism, whereas in Lefka Ori, being $1000 \mathrm{~m}$ lower than Sierra Nevada, dispersal barriers caused by the geographical distance to mainland Greece seem to be the predominant factor.

Of the factors not related to geographical distance, low temperature is considered to be the main cause contributing to orographic isolation in alpine environments (Chapin and Körner, 1994; Price and Barry, 1997; Körner, 2003; Pauli et al., 2003). Most of the endemic species recorded in Sierra Nevada are cryophilic plants restricted to low temperature environments (Molero Mesa et al., 1996). Blanca et al., (2002) report a share of 30-40\% in the upper Sierra Nevada, but it can even reach $80 \%$ at some sites. Endemics were considered to be of fundamental importance for the zonal vegetation of the upper elevation levels, where they accounted for up to about $90 \%$ of vegetation cover on high summits (Pauli et al., 2003). In Lefka Ori, the shorter vertical distance and, hence, the less pronounced thermal gradient, should lead to a 
reduced potential of temperature-related ecological niches and altitudinally distinct distribution patterns. Further, as endemism here is principally favoured by the island position, orographic thermal isolation is of subordinate relevance for the proportion of endemics within a particular elevation zone. Low temperature per se, therefore, cannot be taken as a principal indicator for endemism, but in combination with orographic isolation and the Pleistocene history (i.e. not full glaciated mountains would favour endemism). Whereas the proportion of the endemics of the entire island of Crete did not much vary among the summits, a previous GLORIA study, comparing very narrowly distributed endemics (restricted to the Lefka Ori), however showed an altitudinal increase in endemics percentages, with $3 \%$ on the lower, $6 \%$ on the second highest and $9 \%$ on the highest summit (Kazakis et al., 2007). Values for the Lefka Ori given by Strid (1996), of 26.6\% Cretan endemics and $10 \%$ single mountain endemics (i.e. restricted to Lefka Ori) above $1500 \mathrm{~m}$ a.s.l. are well in the magnitude found on the summit sites.

Besides altitude, varying substrate conditions in the Sierra Nevada massif -siliceous in the core part including the summits analysed in this study, calcareous in parts of the margins- may further enhance habitat separation (compare Kruckeberg and Rabinowitz, 1985; Médail and Verlaque, 1997).

Finally, as Bergmeier suggests $(1995,2002)$, the floristic composition of the vegetation in the Lefka Ori is influenced by constant land use impact over several thousand years. This may be a further reason explaining the less pronounced altitudinal differences of endemic percentages among the summit sites.

Traditional practices of pastoral farming, but, appear to be relevant in both regions (compare Mc Neill, J. R. 1992). Alterations of natural vegetation through human activities, however, were much more pronounced at lower elevations (compare Nogués-Bravo et al., 2008), but little is known about the actual impact of land-use practices on the species distribution in Mediterranean high mountain areas.

The generally large proportion of endemics in our two Mediterranean study regions, and their accumulation at the highest altitudes in the case of Sierra Nevada, appears to be a common feature of high mountain vegetation around the Mediterranean basin. Similarly, high rates of endemism are known form the Moroccan Atlas mountains (Faverger, 1972), and aboveaverage proportions of endemics in the highest vegetation zones were reported form the Central Apennines (Stanisci et al., 2005) as well as from the highly fragmented and patchily distributed subnival environments of the mountains of Iran (Noroozi et al., 2011).

This situation -a primarily endemic vegetation being concentrated in the uppermost bioclimatic zones- gives rise to the concern that the high 
mountain flora of the wider Mediterranean region is highly vulnerable to impacts of climate warming. Warming-induced biodiversity losses are to be expected, particularly, if temperature increases are paired with decreasing precipitation as was projected for the south of Europe during the upcoming decades (Christensen et al., 2007). A Europe-wide study showed that an increase of more thermophilous species in alpine vegetation across the continent is already discernible (Gottfried et al., 2012); our sites in Sierra Nevada and Lefka Ori were part of this study. An accelerating "thermophilisation" of alpine vegetation will threaten cryophilic species through colonisation of high-elevation habitats by usually more widespread species of lower altitudes. A recent paper provided evidence that species numbers were declining on the southern European summits within less than a decade (Pauli et al., 2012, in press). This deserves fostering comparative monitoring activities in Mediterranean mountain regions.

\section{Acknowledgements}

He set up of the permanent plots and data collection was supported by the FP-5 project GLORIA-Europe (2001-2003) No EVK2-2000-00056 of the European Commission.

\section{References}

Anderson, S. 1994. Area and endemism. Quarterly Review of Biology, 69: 451471.

Graves, G.L. 1985. Elevational correlates of speciation and inter-specific geographic variation in plumage in Andean forest birds. Auk, 102: 556-579.

Barthlott, W., Lauer, W. \& Placke, A. 1996. Global distribution of species diversity in vascular plants: towards a world map of phytodiversity. Erdkunde, 50: 317-327.

Bergmeier, E. 1995. Die Höhenstufung der Vegetation in Südwest- Kreta (Griechenland) entlang eines 2450m-Transektes. Phytocoenologia, 25: 317-361.

Bergmeier, E. 2002. The vegetation of the high mountains of Crete-a revision and multivariate analysis. Phytocoenologia, 32 (2): 205-249.

Blanca, G., Cueto, M., Martínez-Lirola, M. J. \& Molero-Mesa, J. 1998. Threatened vascular flora of Sierra Nevada (Southern Spain). Biological Conservation, 85, 269-285.

Blanca, G., López Onieva M.R., Lorite J., Martínez Lirola, M.J., Molero Mesa, J., Quintas, S., Ruiz Girela, M., de los Ángeles Varo, M. \& Vidal, S. 2002. 
PATTERNS OF ENDEMISM ALONG AN ELEVATION GRADIENT IN SIERRA NEVADA (SPAIN)...

Flora amenazada y endémica de Sierra Nevada. Universidad de Granada. Junta de Medio Ambiente, Junta de Andalucía, Spain.

Castroviejo, S., Laínz, M., López González, G., Montserrat, T., Muñoz Garmendia, F., Paiva, J., Villar, L., Aedo, C., Cirujano, S., Morales, R., Navarro, J., Soriano, C., Gómez Campo, C., Nieto Feliner, G., Rico, E. \& Talavera S. 1986-2009. Flora Iberica. Plantas vasculares de la Península Ibérica e Islas Baleares. Vols. I-VIII, X, XIII-XV, XVIII y XXI. Real Jardín Botánico de Madrid, Consejo Superior de Investigaciones Científicas. Madrid.

Chapin, F.S.I. \& Körner, C. 1994. Arctic and alpine biodiversity. Patterns, causes and ecosystem consequences. Trends in Ecology Evoolution, 9: 45-47.

Christensen, J. H., Hewitson, B., Busuioc, A., Chen, A., Gao, X., Held, I., Jones, R., Kolli, R.K., Kwon, W.T., Laprise, R., Magaña Rueda, V., Mearns, L., Menéndez, C. G., Räisänen, J., Rinke, A., Sarr, A. \& Whetton, P. 2007. Regional Climate Projections. In: S. Solomon, D. Qin, M. Manning, Z. Chen, M. Marquis, K. B. Averyt, M. Tignor \& H. L. Miller (Eds.). Climate Change 2007: The Physical Science Basis. Contribution of Working Group I to the Fourth Assessment Report of the Intergovernmental Panel on Climate Change, pp. 847-940. Cambridge University Press, Cambridge.

Dafis, S., Papastergiadou, E., Georghiou, K., Babalonas, D., Georgiadis, T., Papageorgiou, M., Lazaridou, T. \& Tsiaoussi, V. 1996. Directive 92/43/EECThe Greek "Habitat" project NATURA (2000): An overview. Commission of the European Communities DG XI, The Goulandris Natural History Museum- Greek Biotope/Wetland Center.

Delgado, R. \& Castillo Martin, A. 2001. Parque Nacional de Sierra Nevada. Canseco Editores. Spain.

Faverger, C. 1972. Endemism in the Montane Floras of Europe. In Valentine, D.H. (Ed.) Taxonomy phytogeography and evolution. Academic Press. London.

Gottfried, M., Pauli, H., Futschik, A., Akhalkatsi, M., Barancok, P., Benito Alonso, J. L., Coldea, G., Dick, J., Erschbamer, B., Fernandez Calzado, M. R., Kazakis, G., Krajci, J., Larsson, P., Mallaun, M., Michelsen, O., Moiseev, D., Moiseev, P., Molau, U., Merzouki, A., Nagy, L., Nakhutsrishvili, G., Pedersen, B., Pelino, G., Puscas, M., Rossi, G., Stanisci, A., Theurillat, J.-P., Tomaselli, M., Villar, L., Vittoz, P., Vogiatzakis, I. \& Grabherr, G. (2012). Continent-wide response of mountain vegetation to climate change. Nature Climate Change, 2: 111-115.

Hughes, P.D. \& Woodward, J.C. 2008. Timing of glaciation in the Mediterranean mountains during the last cold stage. Journal of Quaternary Science, 23: 575-588.

Jahn, R. \& Schönfelder. P. 1995. Exkursionsflora für Kreta. Ulmer, Stuttgart. 
Kazakis, G., Ghosn, D., Vogiatzakis, I.N. \& Papanastasis, V.P. 2007. Vascular plant diversity and climate change in the alpine zone of the Lefka Ori, Crete. Biodiversity and Conservation, 16: 1603-1615.

Körner, C. 1994. Impact of atmospheric changes on high mountain vegetation. In Beniston, M. (Ed): Mountain environments in changing climates. Routledge, London.

Körner C. 2003. Alpine plant life: functional plant ecology of high mountain ecosystems. Springer, Berlin, Germany.

Kruckeberg, A.R. \& Rabinowitz, D. 1985. Biological aspects of endemism in higher plants. Annual Review Ecology Systematics, 16: 447-479.

McNeill, J. R. 1992. The mountains of the Mediterranean world. Cambridge University Press, Cambridge.

Médail, F. \& Verlaque, R. 1997. Ecological characteristics and rarity of endemic plants from southeast France and Corsica: implications for biodiversity conservation. Biological Conservation, 80: 269-281.

Médail, F. \& Quézel, P. 1999. Biodiversity hotspots in the Mediterranean Basin: setting global conservation priorities. Conservation Biology, 13: 15101514.

Myers, N., Mittermeier, R.A., Mittermeier, C.G., da Fonseca, G.A.B. \& Kent, J. 2000. Biodiversity hotspots for conservation priorities. Nature, 403: 853858.

Molero Mesa. J. \& Pérez Raya, F. 1987. La Flora de Sierra Nevada. Avance sobre el catálogo florístico nevadense. Ed. Universidad de Granada, Spain.

Molero Mesa, J., Perez Raya, F. \& González-Tejero, M.R. 1996. Catálogo y análisis florístico de la flora orófila de Sierra Nevada. In: Chácon Montero, J., Rosúa Campos, J.L. (eds.) $1^{a}$ Conferencia Internacional de Sierra NevadaConservación y desarrollo sostenible, vol II: Suelos; biodiversidad de Flora y Vegetación. Conservación y restauración, Granada, Spain, pp 271-290.

Mota, J.F., Pérez-García, F.J., Jiménez, M.L., Amate, J.J. \& Peñas, J. 2002. Phytogeographical relationships among high mountain areas in the Baetic Ranges (South Spain). Global Ecology and Biogeography, 11: 497-504.

Nogués-Bravo, D., Araujo, M. B., Romdal, T. \& Rahbek, C. 2008. Scale effects and human impact on the elevational species richness gradients. Nature, 453: 216-219.

Noroozi, J., Pauli, H., Grabherr, G. \& Breckle, S.-W. (2011). The subnival-nival vascular plant species of Iran: a unique high-mountain flora and its threat from climate warming. Biodiversity and Conservation, 20: 1319-1338.

Pauli, H., Gottfried, M., Dirnböck, T., Dullinger, S. \& Grabherr, G. 2003. Assessing the long-term dynamics of endemic plants at summit habitats. Ecological Studies, 167: 195-207. 
PATTERNS OF ENDEMISM ALONG AN ELEVATION GRADIENT IN SIERRA NEVADA (SPAIN)...

Pauli, H., Gottfried, M., Hohenwallner, D., Reiter, K. \& Grabherr, G. 2003. The Multi-Summit Approach. Field Manual, third version. University of Vienna.

Pauli, H., Gottfried, M., Hohenwallner, D., Reiter, K. \& Grabherr, G. 2005. Ecological Climate Impact Research in High Mountain Environments: GLORIA (Global Observation Research Initiative in Alpine Environments)-its Roots, Purpose and Long-term Perspectives. Advances Global Change Research, 23: 383-391.

Pauli, H., Gottfried, M., Hohenwallner, D., Reiter, K., Casale, R. \& Grabherr, G. 2004. The GLORIA field manual - Multi-Summit approach. European Commission DG Research, EUR 21213, Office for Official Publications of the European Communities, European Commission, Luxembourg.

Pauli, H., Gottfried, M., Dullinger, S., Abdaladze, O. Akhalkatsi, M., Benito Alonso, J.L., Coldea, G., Dick, J, Erschbamer, B., Fernández Calzado, R, Ghosn, D., Holten, J.I. Kanka, R, Kazakis, G., Kollár, J., Larsson, P., Moiseev, P., Moiseev, D., Molau, U., Molero Mesa, J., Nagy, L., Pelino, G., Puşcaş, M., Rossi, G., Stanisci, A., Syverhuset, A.O., Theurillat, J.-P., Tomaselli, M., Unterluggauer, P., Villar, L., Vittoz, P. \& Grabherr, G. (2012). Recent plant diversity changes on Europe's mountain summits. Science, 336: 353-355.

Phitos, D., Strid, A., Snogerup, S. \& Greuter, W. 1996. The red data book of rare and threatened plants of Greece. WWF, Athens.

Price, M.F. \& Barry, R.G. 1997. Climate change. In Messerli, B., Ives, J.D. (Eds) Mountains of the World. A Global Priority. A Controbution to Chapter 13 of Agenda 21. The Parthenon Publishing Group, London, UK.

Quézel, P. 1953. Contribution à l'étude phytosociologique et géobotanique de la Sierra Nevada. Memorias da sociedade broteriana, 9: 5-77.

Rackham, O. \& Moody, J.A. 1996. The making of the Cretan landscape. Manchester University Press, Manchester.

Rivas Goday, S. \& Mayor López, M. 1966. Aspectos de la vegetación y flora orófila del Reino de Granada. Anales Real Academia de Farmacia, 31: 34-400.

Stanisci, A., Pelino, G. \& Blasi, C. 2005. Vascular plant diversity and climate change in the alpine belt of the central Apennines (Italy). Biodiversity and Conservation, 14: 1301-1318.

Strid, A. \& Tan, K. 1991. Mountain flora of Greece, $2^{\text {nd }}$ end. Edinburgh University Press, Edinburgh.

Strid, A. 1993. Phytogeograpical aspects of the Greek mountain flora. Frag Floristica Geobot Suppl, 2: 411-433.

Strid, A. 1996. The Greek mountain flora, with special reference to the Central European element. Bocconea, 5: 99-112.

Tutin, T.G., Heywood, V.H., Burges, N.A., Moore, D.M., Valentine, D.H., Walters, S.M. \& Webb, D.A. 1964-1980. Flora europaea, Volumes 1-5. Cambridge Univ. Press. Cambridge U.K. 
R. FERNÁNDEZ, D. GHOSN, M. GOTTFRIED, G. KAZAKIS, J. MOLERO, H. PAULI \& A. MERZOUKI

Van Der Werff, H. \& Consiglio, T. 2004. Distribution and conservation significance of endemic species of flowering plants in Peru. Biodiversity and Conservation, 13: 1699-1713.

Väre, H., Lampinen, R., Humphries, C. \& Williams, P. 2003. Taxonomic diversity of vascular plants in the European alpine areas. In Nagy, L., Grabherr, G., Körner, F. and Thompson, D.B.A. (Eds.). Alpine Biodiversity in Europe-a Europe-wide Assessment of Biological Richness and Change. Springer: 133-148.

Vogiatzakis, I.N., Griffiths, G.H. \& Mannion, A.M. 2003. Environmental factors and vegetation composition, Lefka Ori massif, Crete, S. Aegean. Global Ecology \& Biogeography, 12: 131-146. 
PATTERNS OF ENDEMISM ALONG AN ELEVATION GRADIENT IN SIERRA NEVADA (SPAIN)...

Annexe 1. Checklist of local (le) and regional (se) endemics in Lefka Ori and Sierra Nevada.

Anexo 1. Lista de endemismos locales (le) y regionales (se) en Lefka Ori y Sierra Nevada.

\section{Lefka Ori}

Alyssum fragillimum (Bald.) Rech.f.

Alyssum sphacioticum Boiss. \& Heldr.

Arabis cretica Boiss. \& Heldr.

Asperula idaea Hal csy

Bufonia stricta (Sm.) Gurke subsp. stricta

Carlina corymbosa subsp. curetum (Heldr. ex Hal csy) Rech.f.

Centaurea idaea Boiss. \& Heldr.

Centaurea raphanina Sibth. \& Sm. subsp. raphanina

Crepis sibthorpiana Boiss. \& Heldr.

Cuscuta atrans Feinbrun

Dactylis glomerata L. subsp. rigida (Boiss and Heldr.) Hayek

Draba cretica Boiss. \& Heldr.

Erysimum mutabile Boiss. \& Heldr.

Herniaria parnassica subsp. cretica Chaudhri

Lactuca viminea subsp. alpestris (Gand.) Fer kov

Melica rectiflora Boiss. \& Heldr.

Muscari spreitzenhoferi (Heldr.) Vierh.

Pimpinella tragium subsp. depressa (DC.) Tutin

Satureja spinosa L.

Scutellaria hirta Sibth. \& Sm.

Sedum tristriatum Boiss.

Sideritis syriaca L. subsp. syriaca

Teucrium alpestre Sibth. \& Sm. subsp. alpestre

Verbascum spinosum $\mathrm{L}$.

le

le

le

le

se

le

le

se

le

le

se

le

le

le

le

se

le

le

se

le

se

le

le

le

\section{Sierra Nevada}

Alyssum purpureum Lag. \& Rodr.

Andryala agardhii Haens. ex DC.

Arenaria tetraquetra subsp. amabilis (Bory) H.Lindb.

Artemisia granatensis Boiss.

Biscutella glacialis (Boiss. \& Reut.) Jord.

Campanula willkommii Witasek

Carduus carlinoides subsp. hispanicus (Kazmi) Franco

Chaenorhinum glareosum (Boiss.) Willk.

Cirsium acaule subsp. gregarium (Boiss. ex DC.) H.Werner

Coincya monensis subsp. nevadensis (Willk.) Leadlay

Crepis oporinoides Boiss. ex Froel.

Dactylis glomerata subsp. juncinella (Bory) Stebbins \& Zohary

Draba hispanica Boiss. subsp. laderoi Rivas Martínez, M.E. García \& Penas

Erigeron frigidus Boiss. ex DC. le

se

le

le

le

le

le

le

se

le

se

le

le

le 
Erigeron major (Boiss.) Vierh.

Erysimum nevadense Reut. subsp. nevadense

Euphrasia willkommii Freyn

Festuca clementei Boiss.

se

Festuca pseudeskia Boiss.

Galium rosellum (Boiss.) Boiss. \& Reut.

le

Genista baetica Spach

se

Herniaria boissieri J.Gay

le

Holcus caespitosus Boiss.

le

le

Iberis carnosa Willd. subsp. embergeri (Serve) Moreno le le

Jasione crispa subsp. amethystina (Lag. \& Rodr.) Tutin le

Lactuca perennis L. subsp. granatensis Charpin \& Fernández. Casas se

Leontodon boryi Boiss. ex DC.

Lepidium hirtum subsp. stylatum (Lag. \& Rodr.) Thell.

Leucanthemopsis radicans (Cav.) Heywood

Linaria aeruginea (Gouan) Cav. subsp. nevadensis (Boiss.) Rivas Martínez,

Asensi, Molero Mesa \& F. Valle

Lotus corniculatus L. subsp. glacialis (Boiss.) Valdés

Nepeta amethystina Poiret. subsp. laciniata (Willk.) Ubera \& Valdés se

Pimpinella procumbens (Boiss.) H.Wolff

Plantago nivalis Boiss.

Plantago radicata Hoffmm. \& Link subsp. granatensis (Willk.) Rivas Martínez,

Asensi, Molero Mesa \& F. Valle

Poa minor Gaudin subsp. nevadensis Nannfeldt

Reseda complicata Bory

Saxifraga nevadensis Boiss.

Sempervivum nevadense Wale

le

le

se

le

le

Senecio boissieri DC.

Senecio pyrenaicus Loefl. subsp. granatensis (Boiss. ex DC) Rivas Martínez

Sideritis glacialis Boiss.

Teucrium lerrouxii Sennen

le

le

le

le

le

se

se

le

Trisetum glaciale (Bory) Boiss.

Viola crassiuscula Bory

Vitaliana primuliflora subsp. assoana M.Lajnz 